\title{
Amor em tempo de guerra: Guerra Colonial, a
} (in)comunicabilidade (im)possível

Love in a time of war: The (im)possible (in)communicability of the Colonial War

L'amour en temps de guerre: la Guerre Coloniale, la (in)communicabilité

(im)possible

Helena Neves

\section{(2) OpenEdition}

\section{Journals}

Edição electrónica

URL: http://journals.openedition.org/rccs/1079

DOI: $10.4000 /$ rccs. 1079

ISSN: 2182-7435

\section{Editora}

Centro de Estudos Sociais da Universidade de Coimbra

Edição impressa

Data de publição: 1 Junho 2004

Paginação: 43-63

ISSN: 0254-1106

\section{Refêrencia eletrónica}

Helena Neves, «Amor em tempo de guerra: Guerra Colonial, a (in)comunicabilidade (im)possível »,

Revista Crítica de Ciências Sociais [Online], 68 | 2004, colocado online no dia 01 outubro 2012, criado a 19 abril 2019. URL : http://journals.openedition.org/rccs/1079; DOI : 10.4000/rccs.1079 


\section{HELENA NEVES}

\section{Amor em tempo de guerra: Guerra Colonial, a (in)comunicabilidade (im)possível ${ }^{1}$}

O período da Guerra Colonial (1961-1974) produziu em Portugal profundas alterações de ordem demográfica, económica, social e cultural. Mas se o que é mensurável se encontra, hoje em dia, mais ou menos visível, há uma vertente que praticamente permanece por estudar: as vivências da intersubjectividade, dos afectos e das relações amorosas em tempo de guerra. O que se apresenta é um levantamento empírico desta problemática que urge analisar.

Os efeitos dos conflitos bélicos nas relações amorosas manifestam-se em todos os tempos e culturas. A comédia Lisistrata, do século VI a.C., manifesto de um poder feminino para a paz da autoria de Aristófanes, parece ser o texto mais antigo que aborda, de alguma forma, esta temática. A problemática assume contornos específicos nas guerras do século XX, sejam elas mundiais ou regionais. A questão que se coloca é a de saber como a mudança das práticas e das representações sociais de sexo se reflecte nas relações amorosas, e como evoluem estas representações produzidas e reproduzidas num processo contraditório entre a continuidade do babitus que enforma a identidade feminina e a identidade masculina (continuidade insistente na propaganda governamental dirigida à mobilização de homens e de mulheres) e as rupturas impostas pelas necessidades de uma economia de guerra.

Procederei, num primeiro momento, a uma breve introdução, esboçando analogias entre as duas grandes guerras mundiais e a Guerra Colonial e, num segundo momento, abordarei mais especificamente o caso português.

No final dos anos 60 e início de 70, vários autores começaram a questionar a natureza dos efeitos das guerras, particularmente das grandes guerras

\footnotetext{
${ }^{1}$ O presente trabalho tem, no essencial, uma natureza empírica, visando fornecer a base para uma problematização e fundamentação da análise, que urge realizar, dos efeitos do tempo da Guerra Colonial nas relações amorosas.
} 
mundiais, na situação social da mulher. Tais efeitos eram até então considerados como sendo predominantemente de sentido emancipador. Porém, os trabalhos de James F. MacMillan, em 1977, e os de Gail Braydon e Deborah Thom ${ }^{2}$ sobre as mulheres trabalhadoras no período das guerras mundiais contestam a tese do efeito emancipatório e, como salienta Françoise Thébaud, acentuam o carácter provisório e superficial das mudanças: a guerra teria constituído "um parêntesis antes do retorno à normalidade", teria mesmo bloqueado "o movimento de emancipação que se esboçava na Europa, no início do século" (Thébaud, 1995: 33). Uma análise histórica, ainda que sumária, evidencia efectivamente retrocessos no movimento das mulheres. Assiste-se, na I Guerra Mundial, em França, Inglaterra, Estados Unidos e Portugal, a uma suspensão assumida das reivindicações feministas em resposta ao apelo de mobilização patriótica. No nosso país, na sequência da declaração de guerra entre Portugal e a Alemanha, as feministas, particularmente da Associação de Propaganda Feminista, envolvem-se intensamente na defesa da nação. Constitui-se a Comissão Feminina "Pela Pátria” em 1914 e, em 1916, a "Cruzada das Mulheres Portuguesas", organização considerada de interesse nacional, vocacionada para o apoio aos soldados - através de donativos e de agasalhos recolhidos -, a assistência a afilhados de guerra, a reeducação dos mutilados e a formação de enfermeiras de guerra. As feministas portuguesas tentaram, no pós-guerra, rentabilizar o esforço investido, mas também a sua experiência demonstra a transitoriedade do reconhecimento pelo poder da participação social feminista ocorrida nos anos de guerra, apontada pelos estudos acima referidos.

Nas grandes guerras mundiais e na Guerra Colonial, a mobilização feminina no discurso governamental fundamentou-se na representação social dos sexos, e fundamentou-a por sua vez, reforçando a identidade feminina e a identidade masculina, acentuando a simbologia de um modelo de virilidade masculina e de abnegação feminina, díade intrínseca à cultura e subculturas da guerra. A ocupação feminina dos lugares dos homens era encarada pelo poder como uma necessidade de um tempo de crise. E se o trabalho feminino, ampliando-se a esferas tradicionalmente masculinas, suscitou o temor de masculinização da mulher, o discurso dominante garantia a salvaguarda da feminilidade tão duramente posta à prova (Thébaud, 1995: 45). Em relação à Guerra Colonial, é flagrante o discurso das publicações da Mocidade Portuguesa Feminina, nomeadamente a revista Menina e Moça, e do Movimento Nacional Feminino, nas publicações Presença, Mensagem e Guerrilha.

\footnotetext{
2 Referidos por Françoise Thébaud (1995: 32).
} 
Mesmo o trabalho feminino de assistência apologeticamente enaltecido, durante o tempo de guerra e tão conforme à defesa da feminilidade suscitará inesperadas consequências subversivas, ainda que o seu impacto não seja imediato. A assistência social, mobilizando mulheres voluntárias e incrementando a sua profissionalização, produz uma mobilidade social nova e conduz as mulheres a universos até aí interditos ou condicionados de participação no espaço público, de encontro com o outro. A enfermagem coloca as mulheres, não só perante o sofrimento e fragilidade humanas, fora do âmbito familiar, mas também frente ao corpo masculino, ao risco de perturbação pelo toque de homens desconhecidos, em situações dramáticas, anómalas, de isolamento familiar e vulnerabilidade afectiva. As estruturas do poder conhecem estes riscos, mas ficarão progressivamente mais atentas à importância da presença feminina no apoio psicológico ao esforço da guerra. $\mathrm{Na}$ I Guerra Mundial, a imagem da enfermagem como missão evangélica é ferida por uma representação erótica de evocação de vorazes apetites sexuais das enfermeiras, fantasma masculino esgrimido a par do estereótipo familiar da enfermagem, uma e outra representação simbolizando a eterna dualidade de mulher, anjo ou fatalidade, Eva ou Maria. Tal não parece verificar-se no discurso oficial e oficioso do Estado Novo, que consagra a enfermagem na Guerra Colonial como expressão do espírito missionário e dever patriótico das mulheres, simbolicamente representada como maternidade social. A mesma lógica subjaz à representação das enfermeiras pára-quedistas, cuja missão envolvia riscos: apesar de jovens e bonitas são louvadas pela sua coragem varonil.

Nos estudos históricos e sociológicos sobre os efeitos das grandes guerras nas mutações do protagonismo profissional e social das mulheres, surgem, por vezes, referências ao facto de a guerra, pelo sentimento de efemeridade, a consciência do risco de não haver reencontro, que lhe são inerentes, suscitar outro ritmo e intensidade nas relações amorosas. Michelle Perrot considera que a I Guerra Mundial contribui para "o aparecimento do casal moderno centrado na urgência da realização individual e já não patrimonial” (apud Thébaud, 1995: 52). Porém, são escassas as análises sobre os efeitos das guerras nas relações amorosas. Algumas obras no âmbito de estudos de mulheres focando a infelicidade de mulheres afastadas do mundo do trabalho depois das duas guerras mundiais permitem alguma leitura sobre o ambiente conjugal. Segundo alguma reflexão feminista, ${ }^{3}$ no pós-II Guerra Mundial, entre a interiorização das autonomias conquistadas nos anos da

\footnotetext{
${ }^{3}$ Além dos estudos anteriormente referidos, salienta-se ainda os trabalhos de Knibiehler (1977) e Bard $(1999,2001)$.
} 
guerra e o retorno ao lar no pós-guerra terá resultado a insatisfação em mulheres com estudos médios e superiores, da qual foi porta-voz em França, nos anos 50, o movimento Jeunes Femmes, e que, nos Estados Unidos, surge expressa na obra $A$ mística da mulher da autoria de Betty Friedan, publicada em 1963, acutilante análise sobre o mal estar físico e psíquico, esse problema sem nome que atingia mulheres donas de casa da classe média americana, bem casadas, em lares equipados, desfrutando de condições materiais de qualidade de vida.

\section{Amor em tempo de guerra}

Pelo termo amor não designo unicamente os sentimentos e uniões amorosas e sexuais, mas também as vivências da sexualidade autónomas do amor, que constam de todos os quadros de todas as guerras.

Numa interpretação literal do título, poderia entender-se que me detenho fundamentalmente sobre as vivências amorosas durante os anos da Guerra Colonial, de 1961 a 1974. Não é assim. Nesta designação de tempo de guerra, perspectivo o tempo não como uma mera coincidência temporal restrita em simultaneidade com os anos do conflito e a sua sequência imediata, mas como uma dilação. Em rigor, refiro o tempo que os anos da Guerra Colonial, conjugando-se com outros factores, fizeram emergir de forma decisiva. Enquadro, particularmente, o tempo que, produzindo-se entre 1961 e 1974, ultrapassa este quadro cronológico, numa extensão da guerra e além da duração temporal da guerra. Englobo, também, as profundíssimas transformações das quais a estrutura económica, social e política, constituindo-se como a base inultrapassável, constitui apenas a superfície. Clarifico: ainda que necessariamente implicada, a mutação social que se mede estatisticamente, que se analisa quantitativamente, configura somente o rosto objectivo do tempo produzido nos anos de guerra. O tempo do exterior, digamos. Mas a proposta que apresento é de análise do tempo do interior, o tempo gerado pela interiorização das experiências dos anos da Guerra Colonial vividas, no país, por mulheres e, no terreno da guerra, por homens, e de como esse tempo se revelou e continua a revelar-se nos (des)encontros amorosos ocorridos no regresso da guerra e no retomar da vida em comum, em que umas e outros se descobrem "outros" quando se esperavam os "mesmos". O tempo, numa palavra, das subjectividades e das intersubjectividades.

\section{A escrita literária sobre a guerra colonial}

Algumas vertentes desta temática foram primeiramente abordadas em termos ficcionais. Relativamente à Guerra Colonial, sobressai uma literatura 
de raiz acentuadamente autobiográfica, exercício solipsista sobre as memórias, ainda não muito abundante, mas, na generalidade, de grande qualidade: a literatura de autoria feminina que, situando-se do lugar das mulheres - o lugar das esperas - aborda mais especificamente a relação, mais ou menos estruturada, entre os sexos na retaguarda da guerra, quase unicamente no território das colónias; e a literatura de autoria masculina que, relatando, predominantemente, as experiências dos homens no terreno do combate, contém muitas referências sobre as relações amorosas. E não raramente com uma maior abrangência, porque inclui não só o modo como os homens vivem a ausência das suas mulheres, o seu pudor em confidenciá-lo, posto à prova em situações limite, mas também o relacionamento com as mulheres das colónias, o recurso à prostituição, as doenças venéreas, as paixões inesperadas, as violações, esse crime de todas as guerras.

Mesmo quando a questão amorosa surge apenas de passagem - a referência ao correio, à saudade, ao terror da traição, a solidão dos afectos, o sofrimento sexual, mesmo quando no conjunto da obra aparece em estado de quase vestígio, a literatura masculina representa uma fonte extremamente rica, apelando a uma hermenêutica multidisciplinar. Impõe-se, porém, uma perspectiva crítica. Em primeiro lugar, porque esta literatura é produzida por um grupo social específico: os autores narram quase sempre a sua experiência de oficiais, com um capital cultural diferenciado, e o seu olhar era crítico anteriormente à guerra ou tornou-se crítico no seu decorrer, ou, pelo menos, verifica-se a consciência do absurdo da guerra ou uma sensibilidade de repúdio pela violência. Por outro lado, o desenrolar da memória, enquanto construção literária, pode tornar mais espessa a inultrapassável diferença entre o vivido recordado e o vivido real.

Quanto à literatura de autoria feminina, quase toda nos apresenta mulheres que acompanharam os maridos na mobilização e que, portanto, viveram o tempo da guerra, total ou parcialmente, em África. A experiência que narram resulta de uma vivência de isolamento, de condicionamento no espaço das protagonistas, num país estranho, obrigadas quer pelo imperativo da segurança, quer ainda porque o seu lugar recolhido é objectiva e simbolicamente determinado. É o caso de Percursos (do Luachimo ao Luena), de Wanda Ramos, e de A Costa dos Murmúrios, de Lídia Jorge. A experiência narrada diferencia-se da masculina porque é mais personalizada, intimista, enquanto as vivências individuais dos autores são profundamente entrecruzadas na vivência de outros, como aliás se evidencia nos testemunhos recolhidos, traduzindo uma iniciação, por natureza, colectiva.

$\mathrm{Na}$ literatura escrita por mulheres, falta, contudo, ainda o outro lado: o das mulheres que, permanecendo num país, durante treze anos, esvazia- 
do de homens, conheceram uma outra abertura do espaço social, experimentaram outras sociabilidades, por força dos imperativos da guerra, relacionados com outros factores, nomeadamente de ordem económica, como o aumento de investimento estrangeiro em Portugal. Enquanto as primeiras, confinadas ao espaço concentracionário das casas e da messe, fazem parte do repouso do guerreiro, as que ficaram tomaram os lugares dos guerreiros em tempo de paz. Apesar das lacunas referidas em termos temáticos, coloco a hipótese de esta literatura na e sobre a Guerra Colonial poder servir como prolegómeno a estudos sociológicos e psico-sociológicos, quer pela hermenêutica a que faz implicitamente apelo, quer porque pode incluir intencionalmente o recurso a testemunhos directos. Embora a memória constitua sempre uma construção, na qual se filtram materiais, se adoçam ou não arestas, se transformam representações, esta construção é, no depoimento, mais imediata, enquanto a criação do romance a faz passar pela mediação da escrita literária. Neste sentido, importa salientar uma experiência que, partindo do campo literário se constituiu como uma extraordinária reserva de fontes testemunhais sobre a Primeira Guerra Mundial, a ser trabalhada por historiadores e sociólogos franceses. Refiro a iniciativa do escritor Roger Boutefeu, que, no início dos anos 60, publicou em jornais da província um anúncio pedindo testemunhos inéditos dos combatentes da I Guerra Mundial. Obteve, assim, 425 testemunhos, que lhe serviram de base para a obra Les camarades, soldats français et allemands au combat 1914-1918, publicada em 1966, pela editora parisiense Fayard. A documentação compreende

um volumoso conjunto de documentos: dois enormes pacotes, com um peso superior a 45 quilos, e contendo quer diários da guerra, quer relatos dactilografados, [...] inumeráveis testemunhos manuscritos, de humildes combatentes sem patente, alguns redigidos em mau papel escolar, com uma ortografia comovente. (Prost, 1977: 5, 6)

O processo desencadeado por Roger Boutefeu, permitindo obter uma amostra mais representativa das vivências da guerra e, portanto, uma outra visualização no plano social, configura hipóteses de interdisciplinaridade potencialmente muito vastas. Mas já anteriormente, e independentemente da intencionalidade do escritor, a literatura sobre a guerra, em particular a autobiográfica e memoralista, parece ter um efeito de provocação testemunhal. Nas entrevistas que referirei, todos os ex-combatentes reconhecem que as obras sobre a Guerra Colonial, escritas por pares, parecem tornar menos impossível o dizer, após um primeiro momento crítico da sua recepção. 
Foi como se voltasse lá. (Alferes, comissão em Angola)

Tempo reencontrado, reabertura de uma ferida de impossível cicatrização, imersão da memória naquilo que se preferia não lembrar. Os entrevistados referem sobretudo Os Cus de Judas, de Lobo Antunes, publicado em 1979, e Autópsia de um mar em ruínas, de João de Melo, publicado em 1984. Dois entrevistados declaram que a primeira obra, contestando o silêncio instalado, os perturbou bastante. ${ }^{4}$

\section{Vozes de mulheres e de homens comuns}

A proposta que apresentei de análise do que chamei amor em tempo de guerra tem como base um trabalho de âmbito meramente jornalístico. ${ }^{5}$ Dada a sua natureza e âmbito, optei por recolher histórias de vida e realizar algumas entrevistas dirigidas. Procurei, em primeiro lugar, chegar a mulheres de diferentes estratos socioeconómicos que tiveram familiares - maridos, namorados, irmãos, filhos - na guerra. Num segundo momento, porque se impõe uma perspectiva relacional, entrevistei homens combatentes, que projectava seleccionar de diferentes estratos sociais e num quadro proporcional segundo as diferentes colónias. Contudo, não foi possível seguir rigorosamente o critério planeado, porque se se pode seleccionar no universo das mulheres uma amostra relativa ao estrato social ou ao espaço geográfico, o mesmo tipo de selecção resulta difícil, e afigura-se limitado, para o universo masculino. Foram mobilizados cerca de 800000 homens, dos quais morreram cerca de 8000 , contando-se cerca de 110000 feridos e doentes, 4000 deficientes físicos e, estima-se, cerca de 100000 vítimas de stress de guerra. A questão torna-se complexa, não pela heterogeneidade deste universo masculino, mas pelo facto de sujeitos de diferentes meios socioculturais terem vivido, nos mesmos locais, a mesma experiência que, pela sua anormalidade, criou elos singulares. Todos eles, actores sociais do confronto bélico, ficaram irreversivelmente marcados por esse protagonismo, que thes conferiu uma condição: a de (ex)combatente. Se é, efectivamente, difícil traçar com rigor o perfil do combatente, dada a diversidade de meios sociais de origem, classe social, território, cultura, sensibilidades e ideologias, a guerra, independentemente das diferenças individuais, representa para todos

\footnotetext{
4 "Porque camandro é que se não fala nisto? Começo a pensar que o milhão e quinhentos mil homens que passaram por África não existiram nunca e que lhe estou contando uma espécie de romance de mau gosto impossível de acreditar..." (Antunes, 1979: 67).

${ }_{5} \mathrm{O}$ trabalho que suscitou estas entrevistas visava ser publicado na revista Mulheres que, entretanto, interrompeu a sua edição em 1989. Retomou-a depois durante um ano, mas, no início de 1991, deixou, em definitivo, de publicar-se.
} 
uma experiência fundadora de um estado, de uma condição: a de combatente. Experiência individual e individualizada, mas irreversivelmente colectiva, funda uma comunidade de situação, de exílio e também de passagem.

A análise dos efeitos da guerra nas vivências amorosas masculinas torna-se especialmente complexa pelo facto de impor um conhecimento rigoroso, documentado, das diversas vertentes das vivências no contexto do território de combate. No entanto, apesar da escassez de dados, as dificuldades que referi na aplicação do critério de pertença social, a morosidade natural das entrevistas, particularmente em relação ao universo masculino, a natureza do trabalho, não inserido no campo académico, o seu carácter empírico, que não permite definir conclusões, mas apenas hipóteses de enquadramento, as vozes que aqui trago conseguem permitem vislumbrar a natureza de alguns dos problemas das vivências amorosas, nomeadamente no período pós-desmobilização, por efeito da guerra.

Entrevistei vinte e sete mulheres do meio urbano, ${ }^{6}$ da classe média baixa e da classe média, a maioria com instrução secundária incompleta. E entrevistei 16 ex-combatentes. Não entrevistei soldados nem cabos. Apenas sargentos e oficiais oriundos do meio urbano e com escolaridade média ou superior, quase sempre incompleta porque alguns eram estudantes universitários na altura da mobilização. Estas entrevistas não são equilibradas quanto à distribuição geográfica da vivência da guerra: 11 correspondem a comissões, às vezes repetidas, na Guiné; 3 em Moçambique e apenas 2 em Angola. Foram entrevistas muito difíceis, porque é enorme a barreira de silêncio, ${ }^{7}$ de que apenas terão tocado a superfície e porque nesta problemática infiltra-se o inabordável.

No percurso destas mulheres e destes homens pelo tempo da guerra sucedem-se três momentos: o da pré-mobilização, com os homens inseridos já no serviço militar; o período de prestação de serviço no território da guerra, em África; e o período pós-desmobilização. O segundo momento, o da

\footnotetext{
${ }^{6}$ Recolhi também dois depoimentos de mulheres do meio rural, os quais, não sendo representativos como amostra das mutações desencadeadas pela guerra no espaço rural, permitem a hipótese de a problemática em causa se colocar de forma ainda mais densa neste contexto. Cito o exemplo de uma mulher de Portel. Casou muito nova, quando da mobilização do namorado. O marido morreu em Angola em 1973, deixando-a viúva aos 22 anos. Passava os trinta anos quando a entrevistei e continuava de negro, com xaile dissimulando o corpo, lenço cobrindo os cabelos, meias sem transparência, blusa fechada de mangas compridas, censurada por vizinhas porque estava no interior de sua casa de porta aberta, com o lenço colocado para trás. Outra mulher, agricultora de Ansiães, contou que, com a ida do marido para a guerra, pela primeira vez passou a ir vender os animais à feira do gado, aprendeu a passar cheques, meteu-se em "coisas de homens".

7 Ao contrário das entrevistadas, alguns dos entrevistados manifestaram o desejo de se omitir o nome e outros elementos. Daí ter-se optado por um critério comum de identificação dos ex-combatentes, referindo apenas a patente e a colónia onde ocorreram as comissões.
} 
ausência, domina os outros momentos - experimentada, no período prévio, como uma antecipação ansiosa, essa ausência é vivida depois do regresso como um denso hiato relacional, na maioria dos casos complexo de gerir.

Logo que ocorria o recrutamento, a ausência, antes de ser um facto, surge como um factor de inquietação que parece alterar o ritmo da relação amorosa. Várias entrevistadas expressam, como efeito da iminência da mobilização, uma maior vibração sentimental.

A paixão parece que ficou mais acesa. (Carlota, 42 anos, empregada de comércio) Percebi como o meu namorado era importante para mim. (Fátima, enfermeira) Não sabia como iria suportar a ida dele. (Manuela, 41 anos, empregada de escritório)

Mulheres e homens referem exemplos em que a proximidade da mobilização surge como factor de precipitação da estabilidade da relação, embora no universo dos entrevistados tal se verificado apenas num caso:

Se não fosse a mobilização, não tínhamos casado e era escusado o que passámos no meu regresso até ao divórcio. (Furriel, comissão em Angola)

Deste primeiro momento, marcado pelo recrutamento e a mobilização, todos os entrevistados, mulheres e homens relatam a partida do Cais de Alcântara como a primeira de uma série de provações bem mais pungentes do que haviam imaginado.

Parecia que não estava em mim, era como um sonho. Quando ele subiu para o barco eram tantos os homens que deixei de vê-lo, acenava sem saber onde ele estava, por mais que olhasse não o via e depois quando o navio começou a afastar-se e ficar cada vez mais pequeno, chorei, chorei, não quero que me lembre, e as senhoras do Movimento Nacional Feminino a ralhar porque nós, as mulheres e as mães choravam e algumas gritavam. (Carlota, 42 anos, empregada do comércio)

As gajas do MNF andavam por lá todas sorridentes a dar-nos cigarros, livros de bolso, cordel, só cordel, e meias, vejam bem, meias! E a dizer que não havia motivos para aquela aflição das nossas mulheres e nós, tão aflitos como elas, mas a disfarçar. (Furriel, comissões na Guiné) ${ }^{8}$

\footnotetext{
${ }^{8}$ Refira-se que, nomeadamente na sua imprensa e nas intervenções na rádio, o Movimento Nacional Feminino aconselhava as famílias a não irem despedir-se, para evitar os prantos de "abjectas carpideiras" (Presença, orgão oficial do MNF, n. ${ }^{\circ} 1,1963: 6$ ) suspeitas de serem infiltradas, pois as verdadeiras mães portuguesas abençoariam os filhos sacrificados pela inteireza da pátria (Neves, 2001: 80). A publicação na imprensa de fotografias das partidas seria progressivamente condicionada, vindo a ser interdita em 1969.
} 
Com a partida dos homens, iniciava-se o longo tempo das ausências e das esperas, vividas, segundo ressalta nas entrevistas, com um mesmo sentimento de estranheza, ainda que uma estranheza desigual entre elas e eles. Para os homens era mais brutal, mais imediata, e começava com a chegada.

Para mim África era uma parte do estudo, bem chato, da história do Matoso. E dei por mim lá. Era uma natureza bonita, mas as chuvas, o calor, a humidade, os pântanos, era tudo estranho. (Alferes miliciano, comissão em Angola)

Uma estranheza crescente, uma iniciação num outro mundo, a que se acostumavam como estratégia inconsciente de sobrevivência.

Felizmente a gente habitua-se a tudo, se não dávamos em malucos. E no meio daquilo fazíamos amizades, o jogo de cartas ajudava a passar as noites e a bebida também ajudava. No meio dos copos dizia-se uma piada, falava-se da vida, do regresso... (Furriel, comissão na Guiné)

De uma outra forma, menos aguda, as entrevistadas acabam por verbalizar sensações de estranheza quer quando dizem como foi árduo habituarem-se à ausência dos seus homens, quer quando falam das situações daí derivadas. Muitas das entrevistadas (concretamente, dezanove) começaram ou recomeçaram a trabalhar. A entrada no mercado de trabalho surge como um marco distintivo do antes e do depois na vida destas mulheres, através do acesso a uma autonomia, da qual, mais do que o salário, é salientada a aprendizagem de uma outra gestão dos recursos e da vida quotidiana.

Ao princípio custava-me muito levantar-me cedo, mas conviver com outras mulheres, éramos muitas nos Armazéns, e receber dinheiro ganho por mim, sabia-me tão bem. Antes de eu trabalhar, tinha mais tempo mas fazia menos coisas. (Carlota, 42 anos, empregada do comércio)

Lembro-me que a primeira vez que passei um cheque, enganei-me e tive de passar outro. E não era uma analfabeta, tinha o sétimo ano. Só depois da guerra é que tirei o curso. (Maria, 45 anos, engenheira)

É surpreendente como passar um cheque é referido pelas mulheres como sintoma da autonomia que a guerra provocou. Depositar dinheiro, ir pagar contas, mesmo as domésticas (electricidade, telefone), tratar dos impostos e contribuições, comprar bens de equipamento, gerir sozinha a casa - tudo 
isto surge como uma incursão num domínio até aí masculino. Ter, de repente, tempo livre, porque o jantar não tem de estar na mesa a horas, é sentido com surpresa pelas mulheres casadas.

Ao princípio faltava-me qualquer coisa. Não sabia o que fazer. Andava em casa de um lado para o outro, limpava o pó, inventava que fazer. A dada altura começou a saber-me muito bem, ter tempo para fazer o que queria e podia não querer fazer nada. (Manuela, 41 anos, empregada de escritório)

A travessia de uma situação para outra, com maior abertura e responsabilidade pessoal, não se processava pacificamente. A transição implica adaptações, aprendizagem, contradições, percepcionadas com alguma perplexidade, nem sempre cómodas.

Eu antes não tinha auto-estima, independência, e até gostava, acho que alimentava a ideia de uma certa incapacidade a que o meu marido achava graça. As coisas tornaram-se, por um lado, mais difíceis. (Carlota, 42 anos, empregada de escritório)

O alargamento das sociabilidades, a emergência de novas amizades, verifica-se no quadro das novas vivências de maior autonomia, ocorrendo frequentemente como resultado da convivência no meio profissional. Ir a um café, ir ao cinema com amigas ou, mais raramente, sozinha, começam por surgir como aventuras que depois se banalizam.

Pelo contrário, as amizades entre os homens no terreno da guerra eram tecidas num contexto de partilha de insegurança, dor e confronto com situações limite.

O que passámos juntos criou laços muito fortes, às vezes não fáceis de compreender. Nenhum outro tipo de amizade é como estas da guerra. Até posso gostar mais de um ou outro amigo do trabalho ou da escola, mas não é igual. Só os que por lá passaram sabem como é. (Capitão, comissão em Moçambique)

Só com os amigos que lá fiz, alguns nem são assim tão amigos, mas só com eles me sinto bem. (Furriel, comissão na Guiné)

Observa-se também que, embora com muito menor frequência, alguns ex-combatentes não fizeram amizades e não querem manter qualquer contacto com companheiros de armas:

Éramos só isso, companheiros de armas. Fizemos e passamos juntos coisas inesquecíveis. Mas fora um caso ou outro, não tínhamos nada em comum quando nos 
encontrámos, não escolhemos encontrarmo-nos naquela situação e momentos de grande ligação, que os houve sem dúvida, foi no campo da guerra. Na paz não tenho nada para lhes dizer, não quero encontrar ninguém dessa altura, não quero nada que me faça lembrar o que não posso esquecer. (Alferes, comissão em Angola)

Algumas entrevistadas confessam que tinham "um certo cuidado" no contar aos namorados ou maridos "certas coisas, sem importância como ir ao cinema", por receio de que não entendessem, as censurassem ou julgassem que elas não tinham saudades. Coloca-se a hipótese de que as mutações na vida das mulheres, relatadas nas cartas aos homens, pudessem provocar um sentimento de insegurança que, embora não constituindo o único factor, concorresse para rupturas em namoros, por vezes de longa duração, decididas pelos combatentes debaixo de carga emocional.

Quando regressasse logo se via. Assim não havia compromisso, ela ficava livre. (Furriel miliciano, Moçambique).

\section{Amor e sexualidades em tempo de ausência}

Em todas as entrevistas, o correio surge mencionado como o elemento que torna suportável a insuportabilidade da separação. As cartas constituem o único meio de contacto entre os homens ausentes e as mulheres que os esperam. É pelo correio que passam a saudade, as afirmações de amor, o encorajamento mútuo. É pela chegada do correio que as mulheres sabem que os homens estão vivos e os homens sabem se são esperados e amados. As mulheres referem a ansiedade, o desassossego quando as cartas tardavam.

Ficávamos com o coração nas mãos. Os maus pensamentos vinham logo. (Fátima, enfermeira)

Mas é no terreno da guerra nas colónias que o correio assume uma importância que alguns dos entrevistados designam por "vital":

Não era só a ansiedade de termos notícias, a saudade, mas também o modo como os outros chateavam os que não recebiam cartas. Não era por mal mas havia logo bocas um bocado cruéis: "Já estás enfeitado", "pôs-te os cornos", como calcula a linguagem mais vernácula não era a dos oficiais. Mas, depois, quando viam o companheiro em baixo tentavam consolar. Diziam, "És maluco, a miúda gosta mesmo de ti". (Sargento, comissões em Angola) 
Refira-se que a importância do correio na manutenção da ânimo das tropas motivou em todas nas grandes guerras do século XX um investimento estatal, directo ou indirecto, no âmbito do esforço psicológico de apoio à guerra, nomeadamente utilizando as organizações oficiais ou oficiosas de mulheres. No caso da Guerra Colonial, o correio foi objecto de uma acção programada e eficaz do Movimento Nacional Feminino através da criação e ampla distribuição dos aerogramas, os papa-estradas, e da organização de uma rede de madrinhas de guerra, que, à semelhança de outros países, nomeadamente desde o primeiro conflito mundial, visava em particular soldados de famílias não alfabetizadas e famílias de parcos meios. Como é evidente, para jovens sem relações afectivas femininas, a madrinha de guerra representava a ligação mais contínua com o país, mulher sem rosto ou quanto muito de rosto numa fotografia de passe, mas a única que os ouvia, quase a única que lhes escrevia regularmente, a que, de vez em quando, lhes enviava lembranças. Daí o frequente envolvimento emocional por parte dos homens referido, em tom de censura, na imprensa do Movimento.

[S]oldados [que] tomam para com as Madrinhas atitudes de intimidade sentimental que, por serem inoportunas e grosseiras, magoam as senhoras que tão generosamente se prontificaram a dar-lhes o amparo material que nunca pode nem deve ser excedido. ${ }^{9}$

A solidão afectiva, mesmo se mencionada pelas entrevistadas como muito dolorosa, não assume o tom amargo das declarações dos homens. Ao contrário dos homens, elas nunca relatam a privação da vivência sexual como dramática. Das entrevistas com os ex-combatentes ressalta como o desejo acossava os homens. Desejo das mulheres que deixavam no país. ${ }^{10}$ Desejo de qualquer mulher, de um qualquer corpo, no qual se esquecesse, mesmo num momento breve, a guerra, através do qual se afirmasse, mesmo efemeramente, que se estava vivo.

Os que tinham noiva ou mulher continham-se mais. Os que não tinham, queriam qualquer uma. Não importava a cara, nem se lembravam depois dela, alguns era de pé, era só aliviarem-se. (Sargento, comissões em Angola)

\footnotetext{
9 "Carta Aberta ao Caro Militar", folheto Por Deus e pela Pátria, Lourenço Marques, Ed. da Comissão Provincial do MNF, Moçambique, Maio de 1963.

${ }^{10} \mathrm{O}$ desgaste da solidão, da saudade, nos combatentes tornou-se de tal modo problemático que, em 1969, o Estado criaria condições de incentivo para a deslocação das famílias dos oficiais e, em Agosto desse ano, estipulava-se que as famílias deveriam permanecer no "território ultramarino" pelo menos doze meses.
} 
Às vezes estávamos nós há semanas e semanas sem ver uma mulher branca e apareciam as gajas do Movimento Nacional Feminino. Ninguém gramava o movimento, mas naquelas ocasiões a gente comia-as com os olhos. Elas sabiam-no e deviam pensar nisso quando fornicavam com os maridos. (Furriel, comissões na Guiné) ${ }^{11}$

Daí que a prostituição tenha representado outro suporte significativo do processo de mecanismo psicológico pela manutenção do estado de espírito dos homens na guerra. Quando existia a promessa ou a expectativa de que no aquartelamento os aguardavam prostitutas, os homens portavam-se com mais ânimo no mato. Quando passavam longos períodos sem recurso à prostituição e lhes era concedida a ida a uma cidade, "chegavam a parecer animais selvagens", relata um oficial entrevistado.

Os entrevistados referem como muito frequentes as doenças venéreas, mas sublinham que este risco não afastava os homens da vivência do prazer e alguns soldados, apesar da incomodidade, pareciam orgulhar-se da contaminação. A doença venérea representaria certamente nestes casos uma ferida simbólica de afirmação viril. Uma vez recuperados, regressavam ao recurso à prostituição com a mesma desprotecção. Aliás, poucos meios tinham de se proteger. Não eram distribuídos preservativos e sobretudo os soldados temiam que as sulfamidas dadas pelos médicos lhes retirassem a potência.

Abríamos a breguilha e o enfermeiro, de bisnaga na mão, besuntava-nos com pomada antivénerea. (Furriel, comissões na Guiné) ${ }^{12}$

A vivência solitária da sexualidade é dita como comum, particularmente entre as patentes mais baixas. Chamavam à masturbação a instituição dos soldados.

Fartavam-se de masturbarem-se para as latrinas. Não era uma vez por outra. Muitos quanto mais se masturbavam mais medo tinham de ficarem doentes. Havia rapazes que perguntavam ao enfermeiro se o líquido não vinha da espinha, se não se esgotava e não ficavam doidos. (Capitão, comissão em Moçambique)

\footnotetext{
${ }^{11}$ Num número da Presença, surge uma fotografia deveras eloquente: mulheres jovens, caravana do Movimento, num palco, em Bafatá, na Guiné, poses nitidamente coquetes frente a uma multidão de militares de braços estendidos. Note-se que o Movimento Nacional Feminino, desenvolverá um investimento de compensação emocional, alimentando fantasias e o sentimentalismo dos combatentes. A Guerrilha "insere duas páginas de telenovelas e imagens de misses estrangeiras e calendários de jovens em biquini que fariam fugir dirigentes da OMEN e corar as da Mocidade Portuguesa Feminina" (Neves, 2001:92).

${ }^{12}$ Companhias inteiras foram atingidas pela blenorragia. Entrevistados da Guiné falam de como o pénis, inchado, infectado, era entalado em talas de madeira.
} 
Entre as entrevistas às mulheres surgem confidências sobre alguns flirts, atracções, uma ou outra mais séria, durante a ausência dos seus homens, vividas e recordadas com culpabilização, uma ou outra com nostalgia.

Quem sabe se eu tivesse ficado antes com o outro, se o meu namorado não estivesse, na altura, em África, se calhar tinha acabado, mas também se calhar não acontecia. (Fátima, 39 anos, enfermeira)

Mas enquanto estes casos não são assumidos como importantes e muito menos decisivos de rupturas, entre os ex-combatentes entrevistados é mencionada a ocorrência de relacionamentos mais sérios com as mulheres das colónias, dos quais alguns, raros, "davam em casamento".

Colegas chegavam lá e enamoravam-se. Um que eu conhecia apaixonou-se por uma moça amulatada, acabou o namoro de cá e quando veio embora, trouxe-a e casou com ela. (Alferes de Moçambique)

Vivi com uma rapariga na Guiné dois anos e mais dois anos. Era lavadeira, comecei por lhe dar roupa a lavar e acabámos a viver juntos. Era cá casado e com filhos. Quando vim de vez chorava ela e chorava eu. Nunca me hei-de esquecer daquela mulher. (Sargento, comissões na Guiné) ${ }^{13}$

Os entrevistados declaram também, ainda que não o assumindo como sentimento pessoal, o medo obsessivo da impotência, de "perder a tesão", entre os combatentes, e o pavor entre os casados de que a impotência se mantivesse uma vez regressados ao país.

Ouvi uma vez uns tipos, eles deram conta de que eu estava a ouvir. Dizia um que nem com um carro de bois era capaz de levantar o coiso, ele não lhe chamava assim como calcula, era mais vernáculo, e o outro que era de Lisboa, respondia-lhe com uma certa piada: "Deixa lá que eu nem com um guindaste". (Capitão, comissão em Moçambique)

A homossexualidade só abordada quando colocada directamente por quem entrevista, é negada com firmeza

No Exército nunca... (Alferes, comissão em Angola)

13 Relativamente a relacionamentos amorosos com mulheres das colónias, relatados pelos entrevistados como não correspondendo a vivência própria mas por conhecimento de casos, na insinuação dos afectos parece verificar-se menor efemeridade na Guiné, meio mais pequeno do que em Moçambique ou Angola, dada a vastidão do território nestas colónias, a dispersão dos aquartelamentos, a maior mobilidade das tropas e uma prostituição branca que parece mais frequente. 
Maior incomodidade suscita a questão sobre a ocorrência de violações como arma de guerra, ou simplesmente praticadas sobre mulheres da população local. No primeiro caso, os entrevistados negam ter assistido a violações nas investidas bélicas, mas conhecem a sua prática em prisioneiras.

Era sabido que em quartéis da PIDE violavam mulheres, acusadas, com razão ou não, de ligação à guerrilha. (Alferes, comissão em Angola)

O segundo caso, violação de mulheres da população, é dado como frequente, como acontecimento quase banal:

As lavadeiras muitas vezes não escapavam. Os soldados e até furriéis não estavam com meias medidas. (Alferes miliciano, comissão em Moçambique)

\section{O regresso: entre o dizível e o indizível}

Se o regresso dos homens é vivido intensamente, como o fim de uma ameaça, como um reencontro ansiado e acolhido com euforia, segundo as declarações de todas as mulheres e da maioria dos homens, frequentemente as tensões pareciam instalar-se quase de imediato no retomar da vida em comum. As entrevistadas não são capazes de determinar uma causa concreta. Algumas reconhecem a contradição interior entre a necessidade de liberdade a que se habituaram na ausência dos homens e a dependência amorosa que tende a perdurar.

Às vezes eu até queria voltar a ser como ele estava habituado a que eu fosse. (Ana, 38 anos, estudante universitária)

Falam sobretudo de um "mal-estar instalado", "silêncios", "estranheza mútua”, mas acabam por identificar sintomas. Eis alguns passos das entrevistas gravadas:

Ele não aceitou que eu tinha mudado. (Luísa, 40 anos, professora do ensino secundário)

Não havia nada a fazer. Depois de ele vir da guerra não nos entendíamos. Ele acusava-me de não ser a mulher com quem casara e eu achava que ele também não era o mesmo. (Maria, 45 anos, engenheira)

Separámo-nos por uma coisa que parece ridícula, foi a gota de água. Foi em 77, cheguei a casa e levava uns folhetos para escolhermos as férias. Ele fez uma fita. Foi mesmo violento, que sempre tinha sido ele a escolher as férias, se agora andava a meu mando. (Carlota, 42 anos, empregada de comércio) 
Contudo, o mais frequente são os desabafos sobre o desajustamento sexual.

Antigamente estava sempre pronto, por vezes até tinha de me esforçar porque nem sempre uma pessoa está para aí voltada, agora ele nunca está com disposição. Estamos mais de um mês que não nos tocamos. (Luísa, 38 anos, empregada de escritório)

Veio desenfreado. Pensei que era pela falta lá na guerra. Mas os anos passaram e continua assim. Diz que sou frígida. Antes nunca me disse tal coisa. Eu trabalho. Tenho actividade sindical e ele quer que eu esteja sempre disposta. E antes preocupava-se com a minha satisfação, agora só ele é que conta. (Manuela, 41 anos, empregada de escritório)

Fez-me sofrer muito. Deixei de prestar como mulher. Ele dizia que uma negra até lhe lambia o rabo, desculpe lá a expressão, e eu não estava para isso. (Lourdes, 37 anos, caixa num supermercado)

Ficou muito afectado e não vejo solução. Só consegue excitar-se, masturbando-se. Não é capaz de penetração. Só fazemos sexo oral. (Fernanda, 48 anos, empregada administrativa)

Divorciámo-nos com certeza por muitas razões mas o que tornou a nossa vida impossível foram os ciúmes do meu marido. Ele considerava que eu estava muito mais activa sexualmente e tinha razão. Mas ele atribuía o facto à experiência que eu teria tido na sua ausência, o que não era verdade. Nunca o traí mas não acreditou. (Cristina, 46 anos, professora do ensino secundário)

Se alguns dos homens entrevistados responsabilizam, por vezes, a mudança que vislumbraram nas mulheres, outros evidenciam a percepção, o lamento, a raiva, de que a vivência da guerra os coloca numa irreversível solidão face à mulher que amam.

Não dá mesmo para contar. Às vezes nem parece verdade o que dizemos. E há coisas que elas não podem entender. Tudo o que se poder dizer, não diz. (Alferes, comissão em Moçambique)

Consideram intransmissível a angústia da espera do ataque, do bombardeamento, a terrível invisibilidade do "inimigo", o enfrentar da morte: a morte dos outros, os outros desconhecidos, e, fundamentalmente, a morte dos amigos.

Um rapaz da minha terra morreu comigo a tentar meter-lhe os intestinos para dentro e a dizer-lhe que se ia safar. Foi o primeiro gajo que vi morrer, logo aquele. Antes ele 
do que eu, mas custou muito. Andei para aí uma semana bêbado. Era a forma de cair para o lado sem o ver, sem sentir as entranhas dele nas mãos, a escorregarem. (Sargento, comissão na Guiné)

Era um gajo porreiro. Filho único, um bocado ingénuo, um bocado verde, mas estava sempre bem disposto. Eu gostava mesmo do tipo. Só embirrava porque ele fumava como uma chaminé e estava sempre a cravar-me. Uma tarde, quando já a caminho da picada, de repente, rebentou uma mina. Ele era só uma massa de sangue mas agarrei-me aos bocados dele e chorei como não me lembro e berrei: "Cabrão de merda não me morras. Eu deixo-te fumar o maço todo”. (Furriel miliciano, comissão na Guiné)

No entanto, a experiência mais indizível é a vizinhança, a possibilidade concreta da sua própria morte.

Ninguém nos prepara para aquilo. Nem deve ser possível. (Sargento, comissões na Guiné)

Entre o incomunicável, intraduzível mesmo para eles próprios, referem a experiência do pânico, "borrarem-se de medo", chorarem clamando pela mãe, os pesadelos antes do combate, em pleno combate, no limiar da morte; o não quererem mexer-se com pavor dos "turras", quererem que os deixassem no mato, as automutilações desesperadas, mesmo arriscando uma deficiência, infligidas para escapar ao horror da guerra.

Nunca pensei que os homens morressem assim, chamando pela mãe como se fossem crianças. Ainda sonho com os “Ai minha rica mãezinha...”. (Capitão, comissão em Moçambique)

Quantos não davam um tiro no pé, nas pernas, para serem desmobilizados, para regressarem. Quantos não atazanavam o médico, quando ele era um gajo porreiro para ele lhes arranjar uma doença. Pediam-lhe quando estavam pelos cabelos ou brincando. Brincando, brincando... (Sargento, comissões na Guiné)

Assim, entre o dizível delas e o indizível deles, entre o verbalizado e o oculto, entre as palavras amargas e os silêncios pesados, situam-se desajustamentos, rupturas mas também a tentativa, por vezes, de reencontro de dois seres que, apesar das enormes mudanças, permanecem ainda os que se amaram.

Pode ser que com o tempo... (Capitão, comissão em Moçambique)

Desde que ele concordou em ir às sessões do stress pós-traumático de guerra, as coisas parecem, às vezes, melhores... (Luísa, empregada de escritório) 


\section{Em conclusão: a urgência de análises multidisciplinares}

Se todas as entrevistas efectuadas expressam a intraduzível dor das ausências e das esperas, é no universo da dezena e meia de ex-combatentes que se vislumbra o mais espantoso sofrimento, dilacerado e dilacerante. As práticas e as representações relativamente ao masculino não pressupõem a fragilidade emocional, manifestada na situação limite que é a guerra, e a vivência desta fragilidade que os homens experimentaram envergonhadamente e com enorme estranheza ora é relatada numa terceira pessoa, ora é representada, dissimulada com alguma brutalidade e um humor não raramente obsceno. Note-se que os entrevistados falam não somente de si, mas também, de uma forma muito intensa, dos seus companheiros ou, como dizem em caso de comando "dos seus homens". Aliás, nas primeiras conversas, falam mais dos outros (ou do que apresentam como outros), do que de si. E falam desses outros como um nós, inacessível aos que não passaram pela guerra. Ressalta das declarações que as experiências partilhadas produziram, quase sempre, um tipo de intimidade entre os combatentes que eles pensam ser incompreensível para as mulheres. Não somente as experiências do horror mas também as outras, as solidariedades, as confidências sobre a mulata ou a negra que os começava a prender, sobre o desejo pelas lavadeiras, muitas vezes não atendido, sobre o receio de que as doenças venéreas os "lixassem para sempre", o fantasma da impotência. E também o medo de não regressarem, de serem esquecidos, de não chegarem a conhecer os filhos, entretanto nascidos, não voltarem a ver os que iam crescendo.

Esta incomunicabilidade parece constituir-se como uma das vertentes mais importantes dos desencontros amorosos no regresso e no pós-guerra. Mesmo quando os ex-combatentes se esforçam por transmiti-las às mulheres amadas, não conseguem reproduzir as experiências que tiveram, como se as coisas ditas se distanciassem das coisas vividas.

Entre a perplexidade e a culpabilização, consciente ou inconsciente, muitos dos ex-combatentes só entre si encontram apaziguamento, através do que alguém já denominou catarsis colectiva. Daí a necessidade, o ritual dos encontros que tantos continuam a cultivar. Como se pertencessem a uma outra espécie.

Por seu lado, as entrevistas realizadas a mulheres revelam, não somente a mágoa da separação, o constante temor de que "acontecesse alguma coisa aos seus homens", mas também a convicção de que a guerra trouxe alterações concretas ao seu quotidiano, que consideram positivas. Nas suas vozes passa o reflexo das profundas transformações do país durante os anos da guerra. Nas suas palavras o testemunho de como, de diferentes maneiras, 
no âmbito das suas vidas, protagonizaram estas transformações. A actividade profissional surge aqui como um patamar decisivo para outras autonomias objectivas, mas sobretudo subjectivas.

Se as estatísticas apresentam num desenho fundamental os traços quantitativos das mudanças sociais, é preciso conjugar, entrelaçar as mudanças qualitativas inscritas no processo das identidades. Neste sentido, a própria natureza empírica do presente trabalho faz apelo a uma análise fundamentada sobre os efeitos da guerra nas relações amorosas, que problematize, entre outras, estas questões:

- de que modo interiorizaram as mulheres as suas novas vivências no tempo das esperas, como viveram a autonomia, em que meios, em que níveis e segundo que variações (de classe, territorial, urbano, rural)?

- de que forma viveram os homens a ausência das mulheres, desde a tropa (a experiência da ausência não se prenunciava logo quando do recrutamento?), ao embarque, ao aquartelamento, à campanha, ao mato, à espera do correio, até às ligações com outras mulheres nas colónias?

- que desencontros provocaram as novas vivências e sociabilidades de parte significativa da população feminina quando do regresso dos homens, elas e eles tornados "outros" e aguardando-se os "mesmos"? Como pode a barreira da incomunicabilidade das experiências pungentes dos homens na guerra fazer avizinhar a morte do amor?

- através de que mecanismos respondeu o regime ao dilacerar das intersubjectividades que a guerra desencadeou, como se processou ideologicamente neste terreno o esforço de guerra do regime, e qual foi aí o papel desempenhado pelo Movimento Nacional Feminino e as madrinhas de guerra, iniciativa que mobilizou mais de 23750 mulheres correspondendo-se com 33400 homens?

Penso que urge a recolha de testemunhos como os que reuni e que, em parte, utilizei como base para este breve levantamento empírico da problemática do amor em tempo de guerra, e o seu enquadramento numa análise profunda num contexto multidisciplinar. $\mathrm{O}$ momento é propício, pois assiste-se actualmente a um significativo desenvolvimento de estudos sobre a Guerra Colonial, no domínio histórico e sociológico e, mais escassamente, no âmbito psicológico e sociopsicológico, no qual se enquadra a questão proposta neste texto. Talvez que o impulso que se observa para estudos multidisciplinares e interdisciplinares sobre a Guerra Colonial corresponda também afinal à passagem de um tempo interior de que necessitámos para o recuperar deste tempo da nossa história. 


\section{Referências Bibliográficas}

Antunes, António Lobo, (1979), Os Cus de Judas. Lisboa: Vega.

Bard, Christine (org.) (1999), Un siècle d'antiféminisme. Paris: Fayard.

Bard, Christine (2001), Les femmes dans la société française au 20ème siècle. Paris: A. Colin.

Knibiehler, Yvonne (1977), La révolution maternelle depuis 1945. Paris: Perrin.

Neves, Helena (2001), O Estado Novo e as mulheres: o género como investimento ideológico e de mobilização. Lisboa: Museu República e Resistência.

Prost, Antoine (org.) (1977), Les anciens combattants et la societé française. Paris: Presse de la Fondation Nationale des Sciences Politiques.

Thébaud, Françoise (1991), "A Grande Guerra. O triunfo da divisão sexual", in Françoise Thébaud (org.), História das mulheres. Porto: Afrontamento, 31-93. 